\title{
Economic Integration of the Visegrad Four and Ukraine in the Context of Historical Narratives and Global Challenges
}

\author{
By Yevhen Savelyev ${ }^{1}$, Mariia Lyzun ${ }^{2}$, Vitalina Kuryliak ${ }^{3}$, Ihor Lishchynskyy ${ }^{4}$
}

\begin{abstract}
The article reveals the historical preconditions for the development of economic integration of Ukraine and the Visegrad Four from the standpoint of challenges relevant to the region of Central and Eastern Europe. The co-existence of the Rus' people (ancient Ukrainians) with the Czech, Polish, Hungarian and Slovak ethnic groups is outlined, highlighting the significant events. They are presented in the context of building good neighbourly relations through overcoming contradictions. V4 is considered as an association of new political and economic order within the framework of European integration processes. The routes of economic integration of Ukraine and V4 have been assessed, revealing that this process is mainly limited to import operations and excludes real sector of the economy. A concept is developed for the V4+UA economic space, specifying the creation of a regionally integrated machine industry with fragmented production within a global-scale network and high added value.
\end{abstract}

Keywords: European integration, European Union, national identity, new economic and political order, Visegrad Four

\section{Introduction}

The Constitution of Ukraine proclaims the European identity of the Ukrainian people and the irreversibility of the European and Euro-Atlantic direction of Ukraine (Konstytutsiia Ukrainy, 1996). These provisions necessitate the development and implementation of a mechanism for the introduction of Western values in Ukraine, which is the ultimate goal of the European integration strategy. In the view of the 'Copenhagen criteria' and Ukrainian realities, Ukraine's Euro-oriented strategic programme should be designed for the long term (probably several decades). After all, the task to be achieved is threefold: political (stability of institutions guaranteeing democracy, rule of law, respect for human rights and protection of minority rights); economic (competitive market economy); and 'membership' (commitments arising from accession to the EU, including recognition of its political, economic and monetary objectives).

For Ukraine, European integration is the direction of public policy that has received the greatest public support in recent years. According to a DW-Trend poll conducted by IFAK

\footnotetext{
| ${ }^{1}$ Doctor of Science (Economics), Professor, Department of International Economics, West Ukrainian National University, Ukraine

${ }^{2}$ Doctor of Science (Economics), Professor, Department of International Economics, West Ukrainian National University, Ukraine

${ }^{3}$ Doctor of Science (Economics), Professor, Department of International Economics, West Ukrainian National University, Ukraine

${ }^{4}$ Doctor of Science (Economics), Professor, Department of International Economics, West Ukrainian National University, Ukraine
} 
at the request of Deutsche Welle, 73 per cent of citizens (excluding territories annexed and occupied by Russia) support Ukraine's accession to the European Union, and 53 per cent believe that European integration should take place within the next 10 years. At the same time, in the east of the country, the outlook on Ukrainian-Russian relations has changed dramatically, as 81 per cent of the population now view them negatively (LB.ua, 2014).

Historical factors detailing how the countries have coexisted in the European territorial space play an important role in formation of the European Union. Although it is not something directly spelled out in the Statute, the context of the documents and the actual practice of accession to the EU implies that this is taken into account. For instance, in 60 years, Turkey has missed five stages of admission to the European Union due to historical contradictions, primarily in internal relations with the Kurdish minority and the unresolved Cyprus issue and other disputes with Greece. The accession process of Northern Macedonia has been extended for many years due to Greece not recognising the name 'Macedonia'.

The enlargement that the European Union has experienced to date shows that dialogue with neighbouring countries is of particular importance for the admission of new countries. In paving the way to a Greater Europe, Ukraine's priority is to maintain good and mutually beneficial neighbourly relations with Central and Eastern European countries, as Ukrainians and their peoples shared a common destiny being part of various states over the centuries. Good neighbourly relations were maintained with them in those historical times when the Ukrainian territories of old gained sovereignty, namely in the days of Kievan Rus, independent ancient Rus principalities, the Zaporozhian Host and the Hetmanate, the Khan's Ukraine, the Ukrainian People's Republic, the Western Ukrainian People's Republic, and the Ukrainian state. In addition, Ukrainians in these Central and Eastern European countries make up a large proportion of the Ukrainian European diaspora, which is growing. Therefore, there is every reason to believe that the V4 countries are a necessary step in Ukraine's path to the European Union.

The aim of the article is the definition of historical narratives of the centuries-old evolution of good neighbourliness of the CEE peoples that serve as a determinant in creating new forms of integration between Ukraine and the European Union, priority being given to cooperation with the Visegrad Four.

\section{Research Methods}

The choice of research methods is determined by the interdisciplinary nature of the investigation, which falls at the junction of history, international relations and economics. Therefore, to achieve this aim, it is hypothesised that the neighbouring nations of modern Czech Republic, Hungary, Poland, Slovakia and Ukraine had predominantly positive influences on each other's development of state-building processes. Thus, it is advisable to use the process tracing method (Turchenko, \& Zavadskaya, 2017), using which by adhering to the set sequence it is possible to study the centuries-long process of mutual neighbourly exchange of experience and mutual assistance, as well as international division of labour. Consequently, we are able to determine the cause-and-effect relationship behind the modern states and their nations. In this way, the study enables recommendation of decisions on establishing strategic partnerships of neighbouring 
countries that have special common interests on the continent.

Given that the development of cooperation between Ukraine and V4 countries is directed as an integration process during which the interstate relations are deepened and enhanced, the results of the study should take into account the specifics of international relations, which are characterized by a degree of stability and repetition. Nevertheless, practical solutions must resolve the contradictions that arise from different approaches in the interpretation of events, facts, phenomena and processes that affect the relationship in the past, present or future, which can be challenging.

The historical approach to the development of integration processes of Ukraine and V4 should be considered and used as an important, but not the only method of solving new tasks of cooperation. Instead, in combination with economic and statistical methods, it allows us to formulate sound recommendations by deepening the understanding of the relationship between historical memory and the present, ensuring the prevention of past mistakes.

\section{Literature Review and Problem Statement}

Researchers pay little attention to the long-term development of relationships and interactions within the five states of Central and Eastern Europe as a separate system. Even the version of the Four as a system rarely becomes the subject of scientific investigations. On the other hand, a significant number of publications are devoted to the study of bilateral relations between these countries. Ukrainian-Polish relations are of great interest, which can be explained both by the large resource bases of both countries and the long time together within different states, including the Grand Duchy of Lithuania, the Polish-Lithuanian Commonwealth, the Austro-Hungarian Empire, the Russian Empire. Such closeness of the Ukrainian and Polish peoples in modern conditions manifested in Poland being the first state to recognise the independence of Ukraine in 1991.

The way the peoples of the V4 countries perceive Ukrainians is largely influenced by the historical milestones that defined periods of coexistence and cooperation, on the one hand, and rivalry, especially military, on the other. 'History generates myths and symbols, creates narratives, and after all impacts identities,' note V. Filipchuk, I. Ivashko, and M. Kapitonenko (2019). The historical memory of nations, depending on how it is formed, can promote understanding and cooperation, although it can also provoke conflicts and discord. Publications on historical topics relating to Central and Eastern Europe are illustrated by the instances of rapprochement between kings and princes through arranged marriage and territorial claims. This is especially true of the Cherven cities, which were sometimes captured by the Kyivan princes, and sometimes came under the rule of the Polish state. Conflict periods, especially military events, are described in detail.

The main sources of early events in relations between peoples and neighbouring states are chronicles, which are deepened and detailed by scholars on the basis of government documents, letters, memoirs, and similar primary sources. Scientific and educational literature broadly covers the relations between Poland and Kievan Rus.

Relations between Ukraine and the Czech Republic are presented in a small research base. This can be explained by the fact that over more than a millennium of development of relations between the Ukrainian and Czech peoples there have been virtually no conflicts 
and civilizational contradictions, in contrast to, for example, Polish-Ukrainian relations (Tkachenko, 2013). However, the interest in Ukrainian-Czech relations is gradually growing and the new works reflect dealings from ancient times to the present. If in the first half of XX century they were covered mainly by I. Bryk (1921) and O. Kolessa (1924), now they are studied in scientific institutions of Kyiv, Uzhhorod, Odessa, Kharkiv and other scientific centres of Ukraine. Among them are O. Vahner (2006), R. Korsak (2016), S. Motruk (2006), V. Ryeznikov (2014), I. Tkachenko (2013), P. Chernyk (2009).

The issues of international relations between Ukraine and Hungary are insufficiently covered in the scientific literature. Most sources focus on the $11^{\text {th }}-13^{\text {th }}$ centuries, which can be explained by the generally friendly nature of ties and arranged marriages between the House of Arpad and the Rurik dynasty. Studies of ancient times were carried out mainly in Soviet Ukraine (Ukrainian-Hungarian historical times, 1964).

For researchers of relations between Ukraine and Poland, important sources are stored in the Central Archives of Historical Records in Warsaw, the library of the National Ossolinski Institute (Wroclaw), the library of the Polish Academy of Sciences (Krakow), the Jagiellonian Library (Krakow), the National Library (Warsaw), the library of the Princes Czartoryski Museum (Krakow), the Russian State Archive of Ancient Acts (Moscow), Central State Historical Archives of Ukraine in Lviv, archive of the Institute of History of Ukraine of the National Academy of Sciences of Ukraine.

Much of the information on Polish-Ukrainian relations during several waves of emigration from the territory controlled by the Polish governments is stored in a scattered form around the world in the archives of the Polish diaspora. It concerns the struggle for independence after the national uprisings of the 19th century, WWI and WWII, as well as the Polish People's Republic (Krochmal, 2005). Institutions such as the Polish Historical and Literary Society and the Polish Library in Paris, the Polish Institute and Sikorski Museum and the Polish Library in London, the Józef Pilsudski Institute of America in New York receive the greatest recognition. Many archival sources of Polish origin outside Poland itself present information about relations with neighbouring states, as well as with national and religious minorities, including Ukrainians, who have left Galicia en masse and settled alongside ethnic Poles, mostly in North America since the end of the $19^{\text {th }}$ century. Bilateral relations between Ukraine and Slovakia do not have as extensive a historical record as is typical for Ukraine's relations with other V4 countries. Slovakia, like Ukraine, is a new European country and it is no coincidence that Slovakia considers Ukraine a 'forgotten partner' (Kapitonenko, 2018), 'unknown neighbour' (Vorotniuk, 2016). As relations between Slovakia and Ukraine had been studied insufficiently, the International Centre for Policy Studies (ICPS) prepared a brief overview (2018) of their development. The researchers note an important feature in the history of Ukraine and Slovakia, which is that both countries played second fiddle in foreign relations and domestic policy in the past (Hudak, 2000).

There is a growing interest in the history of international relations with Central and Eastern Europe, including Ukraine, in the Russian Federation. M. Yurasov (2018) published a study on the relations of Rus and its western neighbours in the pre-Mongol period and its rise as a great power. H. A. Sanin (2018) studied the place of Russia and Ukraine in the Westphalian system of international relations and the war against the Commonwealth. Ye. I. Maleto (2018) chose the relations between Middle Age Rus and Constantinople, 
including the Russo-Lithuanian state, as the subject of his research. However, in the publications of Russian scholars, Ukraine and the Ukrainian ethnic lands are considered as part of the interests of the Moscow Empire, and the names 'Rus' and 'Russia' are used as synonyms.

\section{Relations Between V4 and Ukraine as a Centuries-Old Tradition of Good Neighbourliness in the Face of Conflict}

The accession of the V4 countries to the European Union in 2004 meant that the fundamental task this group's creation - rapid integration into Euro-Atlantic associations - was achieved. Since then, the question of the expediency of Visegrad's continued existence has arisen. Be that as it may, the enlargement of the EU at the expense of the V4 did not end the unification of Europe. The analysis shows that it makes sense to preserve the group because it has the potential, firstly, to lobby for common interests in the EU and, secondly, to promote the EU enlargement process using its own experience of the $\mathrm{V} 4+$ model $(\mathrm{Zub}, 2018)$. This was confirmed by the signing of the Kromeriz Declaration on 12 May 2004. Ye. B. Kish rightly notes that the integration of the Visegrad countries into European and Euro-Atlantic structures opens up new opportunities and sets new challenges for their further cooperation on issues of mutual interest. Visegrad Group cooperation will continue to focus on regional activities and initiatives aimed at strengthening the identity of Central Europe (Kish, 2008).

It is often said that you do not choose your neighbours. The history of Ukrainian state over the last millennium largely echoes that of the Czech, Hungarian, Polish and Slovak peoples. While, admittedly, throughout this time there were conflicts and contradictions, they were overcome and the countries developed as European civilizations. Most importantly, the mentality and values of these peoples changed in such a way that every time there were misunderstandings, there were also methods and political will to solve the problem.

The Czech Republic is the only V4 country that has not had conflicts and disagreements with Ukraine over the past millennium. However, this statement can be questioned, given the campaign of Vladimir Vsevolodich (Monomakh) against the Czechs. However, the prince was obliged to carry out this action under an alliance agreement with the Poles. Thus, the Poles were the once with an argument with the Czechs in this event. Instead, Ukraine's relations with the Czech Republic have long been historically mutually beneficial (Table 1), which is a good basis for their further deepening in the future.

Table 1: Certain milestones in the system of Ukrainian-Czech relations

\begin{tabular}{|l|l|}
\hline Milestone & Description \\
\hline $\begin{array}{l}\text { history of relations - episodic conflicts } \\
\text { in more than a millennium of good } \\
\text { dynamics }\end{array}$ & $\begin{array}{l}\text { Prince Volodymyr Vsevolodych (Monomakh) marched } \\
\text { against the Czechs, helping the Poles as allies }\end{array}$ \\
\hline Christianity & originally modelled on the Byzantine rites \\
\hline famous Czechs in Ukrainian history & $\begin{array}{l}\text { Vladislav Opolsky - Czech prince and ruler of Galician } \\
\text { Rus }\end{array}$ \\
\cline { 2 - 2 } & $\begin{array}{l}\text { Pylyp Orlyk (of Czech descent) - Hetman of the } \\
\text { Zaporozhian army in exile and the author of the first } \\
\text { Ukrainian constitution }\end{array}$ \\
\hline
\end{tabular}




\begin{tabular}{|l|l|}
\hline Milestone & Description \\
\hline $\begin{array}{l}\text { both nations as part of Austria- } \\
\text { Hungary dual state }\end{array}$ & $\begin{array}{l}\text { accelerated growth of Ukrainians' awareness of national } \\
\text { identity and national consolidation; national consolidation } \\
\text { of the Czechs }\end{array}$ \\
\hline $\begin{array}{l}\text { friendly relations between the Czech } \\
\text { and Ukrainians after the First World } \\
\text { War }\end{array}$ & $\begin{array}{l}\text { recognition of the Western Ukrainian People's Republic in } \\
1918 \text { and assistance to refugees from Ukraine }\end{array}$ \\
\cline { 2 - 2 } $\begin{array}{l}\text { the geopolitical system of dominant } \\
\text { Soviet influence }\end{array}$ & Slowdown of economic and social development \\
\hline post-Soviet period & Ukraine is an important trading partner \\
\cline { 2 - 3 } & cooperation in the field of energy security \\
\hline
\end{tabular}

Note: Data from Tkachenko, I. (2013) and Korsak, R. V. (2016).

The development of Ukrainian-Hungarian relations has been characterized by good neighbourliness and cooperation for centuries. The Ambassador of Ukraine to Hungary D. Tkach (2009) stated that the relations between the two countries in the past have not been burdened by conflicts and problematic issues. Hungary has given great importance to Ukraine as a state and Ukrainians as a people. This can be interpreted from the fact that it opened official political contracts at the highest level even before the collapse of the USSR, thus showing support for Ukraine's aspirations for independence.

Table 2: Certain milestones in the system of Ukrainian-Hungarian relations

\begin{tabular}{|l|l|}
\hline Milestone & Description \\
\hline $\begin{array}{l}\text { assistance in the search for a new } \\
\text { homeland by Hungarians in Europe }\end{array}$ & $\begin{array}{l}\text { the passage of Hungarian tribes through the modern } \\
\text { territory of Ukraine on the way to Europe }\end{array}$ \\
\hline $\begin{array}{l}\text { political support for the establishment } \\
\text { of the Hungarian state }\end{array}$ & $\begin{array}{l}\text { Kyivan prince Yaroslav the Wise grants protection to the } \\
\text { future king of Hungary Andrew I }\end{array}$ \\
\hline $\begin{array}{l}\text { Arranged marriages between the House } \\
\text { of Arpad and the Rurik dynasty }\end{array}$ & $\begin{array}{l}\text { Predslava (daughter of Vladimir I) - married to Grand } \\
\text { Prince Ladislas the Bold } \\
\text { Anastasia (daughter of Yaroslav the Wise) - married to } \\
\text { King of Hungary Andrew I (son of Vazul) } \\
\text { Eufemia (daughter of Vladimir Monomakh) - married to } \\
\text { King of Hungary Coloman the Learned } \\
\text { Euphrosyne (daughter of Mstislav I of Kiev) - married } \\
\text { to King of Hungary Géza II }\end{array}$ \\
\hline $\begin{array}{l}\text { divergence of political interests } \\
\text { crisis of the Austro-Hungarian absolute } \\
\text { monarchy and the Hungarian } \\
\text { Revolution of 1848-1849 }\end{array}$ & $\begin{array}{l}\text { Hungarian and Rus princes compete for the Galician } \\
\text { throne of the, 13th century }\end{array}$ \\
\hline $\begin{array}{l}\text { Hungary's support of the Ukrainian } \\
\text { struggle for state independence after } \\
\text { World War I }\end{array}$ & $\begin{array}{l}\text { Extraordinary diplomatic mission of the Ukrainian } \\
\text { People's Republic in Budapest, which operated from } \\
\text { January 24, 1919 to the end of May 1924; was the last }\end{array}$ \\
\hline $\begin{array}{l}\text { The Treaty of Trianon in 1920 as part of } \\
\text { the Versailles-Washington system, } \\
\text { which recorded the collapse of the } \\
\text { Austro-Hungarian Empire }\end{array}$ & $\begin{array}{l}\text { Attempts by Hungary to revise the terms of the Treaty of } \\
\text { Trianon, conflicts on the language issue }\end{array}$ \\
\hline
\end{tabular}




\begin{tabular}{|l|l|}
\hline Milestone & Description \\
\hline $\begin{array}{l}\text { Cooperation during the period of } \\
\text { Ukranian independence }\end{array}$ & $\begin{array}{l}\text { Declaration on the Principles of Cooperation between } \\
\text { the Ukrainian SSR and the Republic of Hungary on } \\
\text { Ensuring the Rights of National Minorities (signed on 31 } \\
\text { May 1991) }\end{array}$ \\
\hline $\begin{array}{l}\text { On the Establishment of the Ukrainian Part of the Joint } \\
\text { Ukrainian-Hungarian Commission for Ensuring the } \\
\text { Rights of National Minorities (Document 238-92-n, } \\
\text { current version of June 8, 1996, grounds - 618-96-n }\end{array}$ \\
\hline
\end{tabular}

Notes: Data from International Centre for Policy Studies (2018, October, 24) and The Budapest Times (2019, February 11).

The history of Ukrainian-Hungarian relations is marked by various expressions of good neighbourliness (Table 2). This includes protection against the military threat; peaceful resolution of disputes; marriages; Ukrainians in Hungary and Hungarians in Ukraine being granted top government positions; sheltering of immigrants from the Rus' principalities during the Mongol-Tatar invasion; creation of a Rus-Hungarian anti-Horde coalition; military-diplomatic cooperation between the kings of Hungary and the Galician-Volyn princes; Galicians being granted special rights in Hungary; five hundred years of joint struggle against the Turkish invaders and against the Austro-Habsburg oppression (Lytvyn, 2004).

However, the 20th-century geopolitical processes affected both states in a way that introduced certain challenges to the development of bilateral relations. Ukraine withdrew from the Russian Empire, but was occupied by its successor, the Soviet Empire - the USSR, the consequences of which affect the country even today. Hungary withdrew from the Austro-Hungarian Empire and was burdened by the effects of the First and Second World Wars. This gives special significance to the new modern relations between countries, which should follow the principles of good neighbourliness and mutually beneficial partnership. This process has already started with the increase in the number of working meetings between government officials and parliamentarians of both countries after Hungary's accession to NATO and the creation of V4. It was at the summit of the Prime Ministers of V4 and Ukraine in June 2003 that a statement on behalf of the Presidents was released, proclaiming that the Visegrad Four countries were prepared to cooperate with Ukraine using the V4 +1 formula even after joining the EU (Tkach, 2009). This resulted in the dynamic development of bilateral relations between Ukraine and Hungary.

Ukraine's history of relations with Poland is the longest and richest of all the state-building nations that are currently Ukraine's neighbours in Central and Eastern Europe. As stated in the publication of the International Centre for Policy Studies, prepared with the support of the International Visegrad Foundation (2019), "Over this long period Poles and Ukrainians went through joint fighting against external threats, situational alliances, and wars between each other. They have been united and divided by issues of religion, language, rights, and borders." However, the events of the $20^{\text {th }}$ century became an obstacle in Ukrainian-Polish relations. This is primarily due to the consequences of the UkrainianPolish war and the demarcation of borders after World War II. 
Table 3: Certain milestones in the system of Ukrainian-Polish relations ("remember the past, look towards the future')

\section{Kievan Rus}

independent coexistence with elements of intervention in the struggle for thrones, military conflicts with varying degrees of success, joint struggle against the Tatar-Mongols

Princely era (typical of relations between the courts in Europe)

$>$ Grand Prince of Kiev Sviatopolk the Accursed married the daughter of Boleslaw I the Brave

$>$ Boleslaw I the Brave intervened in the strife in Kievan Rus - supported his son-in-law in the fight against Yaroslav I the Wise, defeated the latter in the battle of Buh, captured Kiev and returned the Cherven cities. However, because of a rebellion of Kyiv residents he had to flee to Poland, capturing Kiev treasury.

$>$ Casimir III, taking into account the ancient traditions of independent statehood of the GaliciaVolyn principality, called himself not only the King of Poland but also the King of Rus (1350 1358). Separate coins and coats of arms were minted for this territory.

\section{Late Middle Ages}

Galicia under the rule of Poland; Polonization and Catholicization of a large part of the Rus nobility; the conclusion of the Brest Union and the formation of the Ruthenian Uniate Church; abolition of the Hetmanate on the Right Bank at the end of the $17^{\text {th }}$ century; exclusion of the Rus (Ukrainian) language from recordkeeping

Poles and Ukrainians in the Moscow Empire (later the Russian Empire)

Although the Moscow authorities preserved the influential position of the Polish intelligentsia in the social structure of the western provinces, the latter supported the Ukrainophile trends, contributing to the emergence of the Ukrainian national movement.

\section{Lithuanian - Polish era of Ukrainian history}

Lviv and Halych recognise Polish supremacy in exchange for confirmation of their privileges

World War I and the struggle of Poland and Ukraine against Bolshevik Russia

struggle for the independence of Poland and Ukraine; newly created Poland and the Ukrainian People's Republic led by Petliura; Poland's support for Ukraine in the fight against Bolshevik Russia; military union of Poland and Ukraine; collisions in Lviv; Polish-Ukrainian war; Riga Peace 1921

\section{Volyn tragedy; Operation Vistula}

$>$ bloody Ukrainian-Polish conflict during World War II in the territory of the Republic of Poland occupied by Nazi troops, where its citizens, who of Polish and Ukrainian ethnic origin had been living together;

$>$ ethnic cleansing by the decision of the party and state leadership of the USSR, the Republic of Poland and the Czechoslovak Republic

\section{Formation of Ukrainian state independence}

Polish parliamentarians participate in the work of the constituent assembly of the Congress of the People's Movement of Ukraine in September 1991 and the establishment of a new model of PolishUkrainian relations; Poland recognises the independence of Ukraine on December 2, 1991, first among foreign states; Poland is Ukraine's second largest trading partner

\section{Retrospective look at Ukrainian-Polish relations}

Ukrainian-Polish relations - more than a millennium of coexistence of two ethnically and culturally related peoples with good dynamics, periods of joint struggle against external threats, situational alliances and civilizational contradictions traditional for all European countries, conflicts and military confrontations

Note: Printed from Lytyyn, M. (2010-2011). 
The milestones selected in Table 3 displaying the development of Polish-Ukrainian relations can be supplemented by both positive and negative facts and events. However, the relations between nations that have coexisted for millennia and entered the second millennium with dignity as independent and democratic states, a priori cannot be dominated by negativity, as it leads only to discord. Nevertheless, the history of PolishUkrainian relations is the evolution of two civilized nations, which as per objectively valid social laws are designed to ride into the proverbial sunset together with positive assets in historical backseat. And although the story is hardly over yet, the history is crucial for faster progress, and for wins to outnumber the losses. We must agree with T. Snyder (2011), "It is for us as scholars to seek these numbers and to put them into perspective. It is for us as humanists to turn the numbers back into people. If we cannot do that, then Hitler and Stalin have shaped not only our world, but our humanity". Shifting blame is meaningless. The history of Eastern and Central Europe or, according to T. Snyder, 'bloodlands' should motivate a new paradigm of productive cooperation, devoid of the misguided narratives of the past.

\section{Strategy of Targeting Integration Processes in the Real Economy Sector of V4 + UA}

Given the European integration strategy of Ukraine, the fact that Visegrad Four has become a powerful institutional resource to promote EU enlargement in the process of its development is one of its most important qualitative features. Such power is the result of the association's experience in accelerated implementation of tasks, the solution of which gives grounds to apply for EU membership and be accepted. However, you can take full advantage of this experience only if you gain membership in V4 first. That is why Ukraine should single out the development of cooperation with V4 as an integral part of its strategy. This does not preclude, on the contrary, it envisages the continuation of cooperation in the implementation of reforms, mainly within the framework of the Association Agreement between Ukraine and the EU.

The task of Ukraine and V4's integration requires a certain capitalization of the parties' assets, the joint use of which would allow them permanent access to added value. The assets of Ukraine that can become a collective source of economic development are human and natural resources, and vast territories, including the land and sea borders as a separate and important factor.

Effective use of the expansion potential of the V4 + UA model requires a strategic approach due to its scale. Currently, the Visegrad Group does not have a common strategy for economic development. Efforts are concentrated mainly on individual projects, in particular energy, road, cross-border, etc. initiatives, which Ukraine is partially involved in. Deeper integration of the neighbouring countries requires the interests of the parties to be balanced in all areas. This would contribute to a significant increase in the capacity of the Five to implement the European Neighbourhood Policy. In these circumstances, Ukraine would be interested in a coordinated partnership to accelerate the process of reforming economic and social life. Regionally for the three, i.e. the EU, V4 and Ukraine, such an integration project would be a way to expand and strengthen the zone of stability, peace and prosperity on the European continent. 
Ukraine's economic integration with the V4 countries is developing mainly in the field of trade. Considering that the countries are neighbours, the volume of Ukraine's trade with the V4 countries is relatively small: in 2018, the Group's share in exports was 14.04 per cent and 11.3 per cent in imports. In addition, with Poland and the Czech Republic, i.e. with the largest economies of the group, the trade balance was negative (Table 4).

Table 4: Ukraine's foreign trade in goods with the EU and V4 countries in 2018

\begin{tabular}{|c|c|c|c|c|c|}
\hline & \multicolumn{2}{|c|}{ Export } & \multicolumn{2}{|c|}{ Import } & \multirow[b]{2}{*}{$\begin{array}{c}\text { Balance, } \\
\text { thousand USD }\end{array}$} \\
\hline & $\begin{array}{l}\text { Thousand } \\
\text { USD }\end{array}$ & $\begin{array}{l}\text { \% of Ukraine's } \\
\text { foreign trade }\end{array}$ & $\begin{array}{c}\text { Thousand } \\
\text { USD }\end{array}$ & $\begin{array}{l}\text { \% of Ukraine's } \\
\text { foreign trade }\end{array}$ & \\
\hline Total & 47334987,0 & - & 57187578,0 & - & $-9852591,0$ \\
\hline \multicolumn{6}{|c|}{ Visegrad Four } \\
\hline Poland & 3257248,5 & 6,89 & 3641921,5 & 6,37 & $-384673,0$ \\
\hline Slovakia & 863926,4 & 1,83 & 525879,4 & 0,92 & 338047,0 \\
\hline Hungary & 1646045,9 & 3,48 & 1260239,9 & 2,20 & 385806,1 \\
\hline Czech Republic & 878035,7 & 1,85 & 1034786,6 & 1,81 & $-384673,0$ \\
\hline V4 Total & 6645256,5 & 14,04 & 6462827,4 & 11,30 & $-45492,9$ \\
\hline
\end{tabular}

Note: Data from State Statistics Service of Ukraine (2018).

At the same time, it should be noted that despite the importance of international trade, the limited cooperation achieved solely through it is insufficient for the development of integration processes. Any integration model in the economic sector cannot be based only on the international movement of goods and services. European integration develops on the idea of a single economic space based on free movement of four factors: goods, persons, services and capital. The use of these freedoms in Ukraine requires the development of cooperation primarily in the field of manufacturing, financial services, and banking, especially investment, services.

It should be noted that V4's investment activity in the Ukrainian market does not correspond to the economic potential of any of its member countries. FDI from V4 countries to Ukraine amounts to $1,282.3$ million USD or 5.2 per cent of EU equity in Ukraine. In these processes, Poland and Hungary dominate among the members of the group. The share of their equity in foreign direct investment of the Visegrad Four countries in Ukraine is equal to 85.3 per cent (46.3 per cent and 39.0 per cent, respectively). The reverse, namely the foreign direct investment from Ukraine to the V4 countries, are even more meagre: 24.8 million USD or 0.4 per cent of FDI to EU countries (Table 5). This indicator shows a lack of balance in the development of international economic relations between the neighbouring countries and the weakness of the diplomatic services of Ukraine in the V4 countries and vice versa.

Table 5: V4's FDI (equity) in the economy of Ukraine and Ukraine's FDI in the economy of the EU and V4 as of 31.12.2018

\begin{tabular}{|l|c|c|c|c|}
\hline & \multicolumn{2}{|c|}{ FDI in Ukraine } & \multicolumn{2}{c|}{ FDI from Ukraine } \\
\hline & Million USD & V4/EU, $\%$ & Million USD & V4/EU, $\%$ \\
\hline Total EU & 24742,7 & -- & 6075,5 & - \\
\hline Total V4 & 1282,3 & 5,2 & 24,8 & 0,4 \\
\hline \multicolumn{4}{|r}{} \\
\hline
\end{tabular}




\begin{tabular}{|l|c|c|c|c|}
\hline \multicolumn{5}{|c|}{ by individual country and share } \\
\hline & $\begin{array}{c}\text { FDI from V4 in } \\
\text { Ukraine, million } \\
\text { USD }\end{array}$ & $\begin{array}{c}\text { Share of FDI from V4- } \\
\text { member to total FDI } \\
\text { from V4 in Ukraine, \% }\end{array}$ & $\begin{array}{c}\text { FDI from } \\
\text { Ukraine in V4, } \\
\text { million USD }\end{array}$ & $\begin{array}{c}\text { Share of FDI in V4- } \\
\text { member to total FDI in } \\
\text { V4 from Ukraine, \% }\end{array}$ \\
\hline Poland & 593,9 & 46,3 & 6,7 & 27,0 \\
\hline Slovakia & 74,3 & 5,8 & 0,4 & 1,6 \\
\hline Hungary & 500,1 & 39,0 & 16,8 & 67,7 \\
\hline Czech Republic & 114,0 & 8,9 & 0,9 & 3,6 \\
\hline
\end{tabular}

Note: Data from State Statistics Service of Ukraine (2019).

When developing Ukraine's economic strategy, it is necessary to first direct its integration towards the Polish industrial complex. Features of its intra-industry trade are the basis for this. Machinery, devices and transport equipment have the largest share in Poland's exports and imports. In 2019, it amounted to 38.1 per cent of their imports and 36.3 per cent of their exports (Business Insider Polska, 2020). At the same time, in Ukraine the share of exports of capital goods, transport equipment, and parts and accessories thereof, as well as passenger motor cars according to the statistics of their total volume in 2018 amounted to 3.2 per cent (1.4 billion USD), while imports of the same categories added up to 18.0 per cent (11.5 billion USD) (State Statistics Service of Ukraine 2019).

This state of affairs is the result of a protracted crisis in the Ukrainian economy due to the slow resolution of transformation problems, the lack of systemic market reforms and political disorder. However, Ukraine began post-socialist changes in its economy when automobile, railway transport, energy, aircraft, space, production of equipment for heavy industry, military-industrial complex were among the better-developed industries. This is preserved in the historical memory of the population in the form of psychological readiness for the revival of machine-oriented production of modern products.

It can be predicted that the growing attractiveness of the Ukrainian market among Polish business should provoke a similar reaction from Czech, Slovak and Hungarian entrepreneurs, otherwise this niche will be occupied by companies from other countries. At the same time, Ukraine, firstly, should use the experience of V4 countries in attracting FDI and, secondly, develop levers to increase the interest of their business in the Ukrainian market. According to experts from the German Advisory Group, "The cases of the Czech Republic and Slovakia, which both opened their economies to foreign capital before EU accession, illustrate that openness to international investors can also be a key component of a modernisation strategy" (Saha et al., 2014).

The Czech Republic's interest in integration into the machine industry of Ukraine will grow given that the key products of the Czech Republic's foreign trade are vehicles, especially cars, and it has become the fifth largest producer thereof in Europe. Exports of industrial and electrical equipment are developing equally rapidly.

Strengthening integration processes with the machine industry of Central and Eastern Europe is also promising for Slovakia or, as it is now often called, the 'Tatra Tiger'. Since the 2000s, it has been actively involved in the processes of international division of labour in this field, and it ranks first in the world for the production of cars per capita since 2007. At the same time, the economies of the Czech Republic and Slovakia have historically had and continue to maintain effective relations. Today, Slovakia is the Czech Republic's main 
trading partner aside from Germany, both in terms of exports and imports. With the country's population at 5.4 million, the automotive industry attracts 80 thousand workers. Finally, Hungary has made a serious move towards mechanical engineering in recent years. The country has created favourable conditions for attracting investment, thanks to which many global holdings including Raba, Suzuki, and Mercedes, are willing to build powerful machine-building plants in the country.

Ukraine has a developed sectoral structure of the machine industry and a large market, but the automotive industry is its weak link. At present, it can be considered as a young subsector. The country's car industry has a low level of saturation (219 cars per 1,000 inhabitants in 2018, 71st place in the world (List of countries by vehicles per capita, 2020)). At the same time, a significant part of the population uses used cars. According to the Employers' Federation of Automotive Industry, for every new car bought, four or five used cars are purchased (Biznes, 2020). However, there is a growing trend of demand for new cars. For instance, 88.5 thousand new cars were registered in 2019, which is 8 per cent more than in the previous year (Litvinchuk, 2020).

\section{Conclusions}

Thus, in Central and Eastern Europe there are favourable conditions for the creation of a regionally integrated machine industry with fragmented production within a global-scale network and high added value. The development of this area of integration requires the development of a joint strategy for technology transfer in the field of 4.0 industry, the implementation of which should include research and design institutions, quality human capital, large businesses, small and medium-sized businesses, and multinational banks. To this end, geographical consolidation of macro- and microintegration based on balancing national and local interests must be achieved at the political level from the outset.

Given the scale of the project, its success can be ensured by forming an effective intergovernmental management mechanism. This task should be implemented within the framework of the Visegrad Group, whose decisions on the integrated machine industry should be made with the participation of Ukraine. At the same time, it is advisable to determine the list and principles of legislation that would be submitted for parliaments' consideration. The transformation of relations between Ukraine and the Visegrad Four caused by the integration in this case would take an ad hoc format, which can be represented by the model V4+UA. Its framework provides a basis for joint development and implementation of large interstate projects. Such a strategy of cooperation between the Group and Ukraine would have the potential for further interconnected economic development, which would encourage the search for a corresponding political superstructure. In this context, the transformation of V4+UA into the Visegrad Five (V5) can be considered as one of the options.

The development of integration processes in Central and Eastern Europe will encourage the establishment of other alliances at the regional level. These include the concepts of a partnership bloc of states from the Baltic to the Black and Adriatic Seas, the Intermarium, the Bucharest Nine (B9), Via Carpatia, which have been discussed for decades as viable ideas by both experts and political leaders. 


\section{Acknowledgements}

This work would be impossible without the financial support of the Ministry of Education and Science of Ukraine. The article was prepared as part of a fundamental scientific studies on 'Creation of the alliance of Poland, the Czech Republic, Slovakia, Hungary and Ukraine as the Visegrad Five: the context of regional economic integration' (registration number ME-05-2019 'Б’).

\section{References}

Balvociute, R. . (2020). Social Assistance for Poverty Reduction in the EU Countries: An Aspect of SocioEconomic Sustainability. European Journal of Sustainable Development, 9(1), 469. https://doi.org/10.14207/ejsd.2020.v9n1p469

Biznes, (2020, January 22). Nekontrolovanyi import avtokblama faktychno zmyshchyv rynok novykh avto - blava Federatsii avtopromu [Uncontrolled import of used cars actually destroyed the market of new cars - the head of Federation of Automotive Industry]. Retrieved from https://business.ua/news/8648-nekontrolovanij-importavtokhlama-faktichno-znishchiv-rinok-novikh-avto-glava-federatsiij-avtopromu

Bryk, I. (1921). Materialy do istorii ukrainsko-cheskykh vzaiemyn [Materials on the history of Ukrainian-Czech relations]. Ukrainsko-ruskyi arkhiv, (15), 169.

The Budapest Times (2019, February 11). 'Important milestone' in history of Ukrainian-Hungarian relations. Retrieved from https://www.archiv.budapesttimes.hu/2019/02/11/important-milestone-history-ukrainianhungarian-relations

Business Insider Polska (2020, February 11). Mapa polskiego eksportu i impottu. Wiencej sprzedajemy za granice niž sprowadzamy. Retrieved from https://businessinsider.com.pl/finanse/handel/import-i-eksportpolski-mapa-handlu-zagranicznego-dane-gus-2019/q6phd38

Chernyk, P. (2009). Ukraina v Heopolitychnykh Kontseptsiiakh Chekhii ta Slovachchyny XX st. [Ukraine in the Geopolitical Concepts of the Czech Republic and Slovakia in the 20th Century]. Ukrainska natsionalna ideia: realii ta perspektyvy rozvytku, (21), 172-179.

Filipchuk, V., Ivashko, I., \& Kapitonenko, M. (2019). Ukraine-Poland relations. ICPS. Retrieved from http://icps.com.ua/assets/uploads/images/images/eu/ukr_poland_rozd_a4.pdf

Hudak, V. (2000). Relations between Ukraine and Slovakia: Recent History and Future Opportunities. Retrieved from https://www.files.ethz.ch/isn/90427/2000-01-01_Relations-Between-Ukraine.pdf

International Centre for Policy Studies. (2018, October 24). Kyiv vs Budapest: What's going on in Ukrain-Hungarian relations? Retrieved from http://icps.com.ua/en/studies-icps/foreign-policy/kyiv-vs-budapestwhats-going-on-in-ukrainian-hungarian-relations/

International Centre for Policy Studies. (2018). Ukraine-Slovakia relations: developing a true strategic partnership? Retrieved from http://icps.com.ua/assets/uploads/images/images/eu/ukr_slovakia rozd a4.pdf

Ivashkiv I., H. Kupalova, N. Goncharenko, U. Andrusiv, J. Streimikis, O. Lyashenko, V. Yakubiv, M. Lyzun, I. Lishchynskyy, I. Saukh (2020) Environmental responsibility as a prerequisite for sustainable development of agricultural enterprises. Management Science Letters, Vol. 10, Issue 13, 2973-2984. Retrieved from DOI: 10.5267/j.msl.2020.5.028

Kapitonenko, M. (2018, December 26). Slovachchyna-Ukraina: buduiuchy stratehichne partnerstvo? [SlovakiaUkraine: building a strategic partnership?]. LB.ua. Retrieved from https://ukr.lb.ua/blog/kapitonenko_nikolay/415882_slovachchinaukraina_buduyuchi.html

Kish, Ye. B. (2008). Tsentralna Yevropa v suchasnii systemi yevrorehionalnoi intehratsii: monobrafiia [Central Europe in the modern system of Euroregional integration: a monograph]. Lira.

Kolessa, O. (1924). Pohliad na istoriiu ukrainsko-cheskykh vzaiemyn vid X do XX v. [A look at the history of Ukrainian-Czech relations from the tenth to the twentieth century]. Prague.

Konstytutsiia Ukrainy [Constitution of Ukraine], pmbl. (1996). Retrieved from https://zakon.rada.gov.ua/laws/show/254\%D0\%BA/96-0D0\%B2\%D1\%80\#Text 
Korsak, R. V. (2016). Istorïa ukrainsko-cheskykh mizhderzhavnykh vidnosyn (kinets XX pochatok XXI stolittia) [History of Ukrainian-Czech interstate relations (end of $20^{\text {th }}$ beginning of 21st century)]. Uzhhorod National University. Retrieved from https://dspace.uzhnu.edu.ua/jspui/bitstream/lib/6548/1/Препринт_посібника ._ІІтторія_укаїнсько-чеських_відносин.PDF

Krochmal, A. (2005). Dokumenty z istorii Ukrainy i polsko-ukrainskykh vidnosyn u zbirkakh polonistychnykh instytutsii [The Documents on Ukrainian History and Polish-Ukrainian Relashionships in Collections of Polish Institutions Abroad]. Arkbivy Ukrainy, (4), 60-75.

LB.ua. (2014, December). 73\% ukraintsev podderzbivayut kurs na yevrointegratsiyu [73\% of Ukrainians support the European integration course]. Retrieved from https://ukr.lb.ua/society/2014/12/25/290516 73 ukraintsiv pidtrimuyut kurs.html

Lyzun, M., Lishchynskyy, I., Savelyev, Y., Kuryliak, V., Kurylyak, Y. (2019) Modeling Evaluation of Dollarization Economic Efficiency. 2019 9th International Conference on Advanced Computer Information Technologies (ACIT): Conference Proceedings (Ceske Budejovice, Czech Republic, June 5-7, 2019). Ceske Budejovice, Czech Republic, 366-369. Retrieved from DOI: 10.1109/ACITT.2019.8780024

Litvinchuk, T. (2020, January 9). U 2019 rotsi v Ukraini zareiestruvaly v 3,5 razu bilshe vzhyvanykh avto, nizh rokom ranishe [In 2019, Ukraine registered 3.5 times more used cars than a year earlier]. NV. Retrieved from https://nv.ua/ukr/biz/markets/u-2019-roci-kilkist-reyestraciy-vzhivanih-avto-vukrajini-zrosla-v-3-5-razu-novini-ukrajini-50063179.html

Lytvyn, M. (2010-2011). Pytannia ukrainsko-polskykh vidnosyn u naukovii spadshchyni ta hromadskii diialnosti Yaroslava Isaievycha [Ukrainian-Polish relations in Jaroslav Isaievych's academic legacy and public activities]. Ukraine Poland: Historical Heritage and Public Consciousness, (3-4), 5-13.

Lytvyn, V. (2004). Ukrainsko-uhorski vidnosyny: istorychni tradytsii ta novi obrii spivrobitnytstva [UkrainianHungarian relations: historical traditions and new horizons of cooperation]. Holos Ukrainy, 97(3347). Retrieved from http://www.golos.com.ua/article/234300

Maleto, Ye. I. (2018). Srednevekovaya Rus' i Konstantinopol'. Diplomaticheskiye otnosheniya v kontse XIV seredine XV v. [Medieval Russia and Constantinople. Diplomatic relations at the end of the $14^{\text {th }}$ the middle of the $15^{\text {th }}$ century]. Tsentrpoligraf.

Motruk, S. (2006). Ukrainska Hromada v Chekhii: Istoriia ta Sohodennia[Ukrainian Community in the Czech Republic: History and Present]. Scientific Papers of Kamianets-Podilskyi National Ivan Obiienko University. History, (5), 38-48.

Ryeznikov, V. V., \& Borodenko, M. M. (2014). Ekonomiko -Dyplomatychnyi Aspekt Ukrainsko-Cheskykh Vidnosyn na Suchasnomu Etapi [Current Economic and Diplomatic Aspect of Ukrainian-Czech Relations]. The Journal of V. N. Karazin Kharkiv National University Series: International Relations. Economics. Country Studies. Tourism', 1(3), 61-64.

Saha, D., Giucci, R., Naumenko, D., \& Kovalchuk, A. (2014). Ukrainian Machine Building: Strategic options and short term measures in view of trade disruptions with Russia. German Advisory Group Institute for Economic Research and Policy Consulting. Retrieved from http://www.ier.com.ua/files/publications/Policy_papers/German_advisory_group/PP_02_2014 _en_f.pdf

Sanin, H.A. (2018). Rossiya i Ukraina v Vestfal'skoy sisteme mezhdunarodnykh otnosheniy, 1648-1667 gg. Russia and Ukraine in the Westphalian system of international relations, 1648-1667]. Institute of Russian History of RAS: Tsentr gumanitarnykh initsiativ.

Snyder, T. (2011). Bloodlands: Europe between Hitler and Stalin. Random House.

Sokołowicz, M. E., \& Lishchynskyy, I. (2018). Are Poland and Ukraine gravity centres for each other? Study on the labour migration patterns. Comparative economic research,21(1), 45-65. Retrieved from DOI: $10.2478 /$ cer-2018-0003

State Statistics Service of Ukraine. (2018). Ukraine's Foreign Trade in Goods [Data set]. Retrieved from http://ukrstat.gov.ua/operativ/operativ2018/zd/ztt/ztt_u/ztt1218_u.htm

State Statistics Service of Ukraine. (2019). Cooperation between Ukraine and EU countries in 2018. Statistical Yearbook, 6265. Retrieved from http://www.ukrstat.gov.ua/druk/publicat/kat_u/2019/zb/06/zb_ES_18.pdf

State Statistics Service of Ukraine. (2019). Ukraine's Foreign Trade. Statistical Yearbook, 100. Retrieved from http://www.ukrstat.gov.ua/druk/publicat/kat u/2019/zb/06/zb ztu 2018.pdf 
Tkach, D. I. (2009). Ukrainsko-Uhorski Vidnosyny Novitnoi Doby [Ukrainian-Hungarian Relations of Modern Times]. Annual Journal of the Diplomatic Academy of Ukraine, (15), 78-89. Retrieved from https://www.krok.edu.ua/download/publikatsiji/tkach-dmitro-ivanovich/dmitro-tkachpublikatsiya-012.pdf

Tkachenko, I. (2013). Istorychna Retrospektyva Vzaiemyn Ukrainy z Cheskoiu Respublikoiu [Historical Retrospective Review of Relation between Ukraine and Czech Republic]. Scientific Notes, (4), 260271. Retrieved from http://nbuv.gov.ua/UJRN/Nzipiend_2013_4_26

Turchenko, M. S., \& Zavadskaya, M. A. (2017). Kauzal'nyy Mekhanizm vs Nagromozhdeniye Faktov? Kriterii Otsenki Prichinno-Sledstvennykh Svyazey v Case Studies [Casual Mechanism vs Pile of Facts: How to Evaluate Casual Links in Case Study Research]. Polis. Political Studies, (2), 134-146. Retrieved from https://doi.org/10.17976/jpps/2017.02.09

Ukrainian-Hungarian historical times. (1964). Naukova Dumka. Retrieved from http://history.org.ua/LiberUA/UkrUgIstZv_1964/UkrUgIstZv_1964.pdf

Vahner, O. (2006, August 18). Ukraintsi v Chekbii: maizhe sto rokiv natsionalnoi istorii Ukrainians in the Czech Republic: almost a bundred years of national history]. Retrieved from https://zn.ua/ukr/SOCIUM/ukrayintsi_v_chehiyi_mayzhe_sto_rokiv_natsionalnoyi_istoriyi.html

Vorotniuk, M. (2016). Foreign Policy Audit: Ukraine-Slovakia. Institute of World Policy. Retrieved from https://glavcom.ua/pub/pdf/10/1037/Aud_Ukr_Slovak_01_40_ukr.pdf

Yurasov, M. (2018). Na zapadnykh rubezhakh Rusi [On the western borders of Russia]. Nauka.

Zub, S. (2018). Osnovni Chynnyky Vnutrishnoi ta Zovnishnoi Vzaiemodii Krain Vyshehradskoi Hrupy [The Main Factors of Internal and External Interaction of the Visegrad Countries]. Geopolitics of Ukraine: bistory and modern times, 1(20), 217-235. Retrieved from DOI:10.24144/2078-1431.2018.1(20).231249 